\title{
"Formation of the investment environment in Ukraine in the context of European integration: an example of Poland"
}

\begin{tabular}{|c|c|}
\hline \multirow{7}{*}{ AUTHORS } & Tetiana Ponomarenko (D) https://orcid.org/0000-0002-6734-6212 \\
\hline & $\mathbb{R}$ http://www.researcherid.com/rid/T-5669-2017 \\
\hline & Olena Zinchenko (D http://orcid.org/0000-0003-1156-1148 \\
\hline & Veronika Khudoliei (D) http://orcid.org/0000-0002-6658-7065 \\
\hline & Olha Prokopenko (D http://orcid.org/0000-0003-1362-478X \\
\hline & $\mathbb{R}$ https://publons.com/researcher/1387676/olha-prokopenko/ \\
\hline & Dariusz Pawliszczy (D) https://orcid.org/0000-0003-1328-7891 \\
\hline \multirow{3}{*}{ ARTICLE INFO } & $\begin{array}{l}\text { Tetiana Ponomarenko, Olena Zinchenko, Veronika Khudoliei, Olha Prokopenko } \\
\text { and Dariusz Pawliszczy (2018). Formation of the investment environment in }\end{array}$ \\
\hline & Ukraine in the context of European integration: an example of Poland. Investment \\
\hline & $\begin{array}{l}\text { Management and Financial Innovations, 15(1), 361-373. } \\
\text { doi:10.21511/imfi.15(1).2018.30 }\end{array}$ \\
\hline DOI & http://dx.doi.org/10.21511/imfi.15(1).2018.30 \\
\hline RELEASED ON & Wednesday, 04 April 2018 \\
\hline RECEIVED ON & Monday, 19 February 2018 \\
\hline \multirow[t]{2}{*}{ ACCEPTED ON } & Saturday, 10 March 2018 \\
\hline & $((c))_{\text {EY-NG }}$ \\
\hline LICENSE & $\begin{array}{l}\text { This work is licensed under a Creative Commons Attribution-NonCommercial } 4.0 \\
\text { International License }\end{array}$ \\
\hline JOURNAL & "Investment Management and Financial Innovations" \\
\hline ISSN PRINT & $1810-4967$ \\
\hline ISSN ONLINE & $1812-9358$ \\
\hline PUBLISHER & LLC "Consulting Publishing Company "Business Perspectives" \\
\hline FOUNDER & LLC "Consulting Publishing Company "Business Perspectives" \\
\hline
\end{tabular}

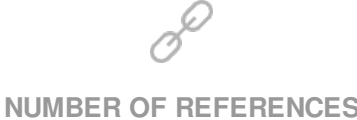

34
NUMBER OF FIGURES

3

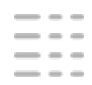

NUMBER OF TABLES

6

(c) The author(s) 2022. This publication is an open access article. 


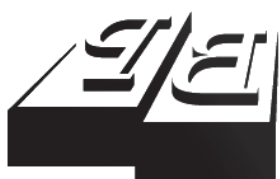

BUSINESS PERSPECTIVES

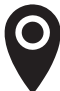

LLC "CPC "Business Perspectives" Hryhorii Skovoroda lane, 10, Sumy, 40022, Ukraine

www.businessperspectives.org

Received on: $19^{\text {th }}$ of February, 2018 Accepted on: $10^{\text {th }}$ of March, 2018

(C) Tetiana Ponomarenko, Olena Zinchenko, Veronika Khudoliei, Olha Prokopenko, Dariusz Pawliszczy, 2018

Tetiana Ponomarenko, Doctor of Economics, Professor, Department of International Economics, Accounting and Finance, Academician Yuriy Bugay International Scientific and Technical University, Ukraine.

Olena Zinchenko, Doctor of Economics, Head of the Department of Business Entities Finance and Innovative Development, Kryvyi Rih National University, Ukraine.

Veronika Khudoliei, Doctor of Economics, Rector of Academician Yuriy Bugay International Scientific and Technical University, Ukraine.

Olha Prokopenko, Doctor of Economics, Professor, Department of Economic Theory, Sumy State University, Ukraine.

Dariusz Pawliszczy, Ph.D., Mayor of Gromadka, Poland.

\section{(ㄷ)(1) $(8)$}

This is an Open Access article, distributed under the terms of the Creative Commons Attribution-NonCommercial 4.0 International license, which permits re-use, distribution, and reproduction, provided the materials aren't used for commercial purposes and the original work is properly cited.
Tetiana Ponomarenko (Ukraine), Olena Zinchenko (Ukraine), Veronika Khudoliei (Ukraine), Olha Prokopenko (Ukraine), Dariusz Pawliszczy (Poland)

\section{FORMATION OF THE} INVESTMENT ENVIRONMENT IN UKRAINE IN THE CONTEXT OF EUROPEAN INTEGRATION: AN EXAMPLE OF POLAND

\begin{abstract}
In the period of Ukraine's integration into the European economic space, one of the basic conditions for achieving compliance with the European community requirements is the formation of favorable investment environment. In view of this, the aim of the article is to analyze the economic preconditions for the unification and adaptation of the investment mechanism in the period of Ukraine's integration into the economic euro area, and to develop recommendations for unification of institutional support for the formation of the investment environment in Ukraine. In the course of the study, the system approach and the method of system analysis and synthesis are the basis. Based on the analysis of the activities in Poland, it is outlined that the conditions for their achievement of high rating indicators are the legally regulated mechanism for promoting investment, which includes relevant institutions, low tax rates, transparency and ease of doing business. The comparison made on this basis has made it possible to determine key differences and problems between approaches of European countries and Ukraine, namely: the lack of correspondence between the actual measures legally declared, the monetary unit instability, the unpredictability of the political and economic situation, the complexity of doing business. Approaches to unification of institutional support for the formation of the investment environment in Ukraine and measures aimed at increasing the efficiency and competitiveness of investment activity are proposed.
\end{abstract}

\section{Keywords}

investment activity, institutional support, unification, European integration, Ukraine, Poland

\section{JEL Classification O16, O19, G31}

\section{INTRODUCTION}

The functioning of the Ukrainian economy in the period of creating conditions for its integration into the economic European space is accompanied by solving a large number of complex and interrelated tasks. Along with handling the strategic economic and political problems at the macro level, such as eliminating geopolitical instability, restoring the domestic economy competitiveness at the world level, improving the quality of economic, social, environmental and other processes, important measures are taken to achieve the required level by criteria of the associate membership in the European Union. At the same time, synchronization of the investment activity mechanism in Ukraine, both at the state level as a whole and at the enterprise level, with the conditions of investment activity in the European Union is one of the basic steps to improve the economic component of such criteria. The improvement of country's investment environment is the basis for the 
economic processes revitalization. The level of indicators reflecting the investment attractiveness of the country's economy is an important characteristic of the positioning by the world community as a whole. Measures to increase the investment attractiveness of the country should be comprehensive and systematic. The effectiveness of investment activity depends on the coherence of the investment environment functioning, therefore, the study of the conditions for interaction between the investment activity subjects is necessary and sufficient to achieve the social development goals. Therefore, the unification of the institutional provision of the formation of Ukraine's investment environment during the period of integration into the European Economic Area is an important and topical issue in the context of developing such measures.

\section{LITERATURE REVIEW}

The main condition for modernization and development of the Ukrainian economy is the attraction of new cash receipts. Many scientists studied the problems of regulating and attracting foreign investment in general, as well as in the context of integration processes.

Thus, the basic principles of investment processes management are described by Ashauer (1989), for example, in "Productive Investment and Productivity in the Group of Seven", the author defines the laws and logic governing these processes. Major and Szilagyi (2009) present a detailed description of the results of conducting an active investment policy of the European Union, with the development of appropriate models for analyzing the consequences of each of the functional changes in European countries' investment strategies. The authors determine the complexity of large state investment projects and consider ways to correct them by performing an analysis of the dynamic process sensitivity to the parameters of a model for identifying influential economic parameters in an open economy.

Awolusi and Adeyeye (2016) investigated the factors of the efficiency and success of foreign direct investment (FDI), confirming the significant link between them and the country's economic growth.

Tkachuk (2017) devoted her research to investing in the banking sector. She notes that investment operations are ranked second among the assets held by banks in Ukraine. The author also noted that due to a significant increase in their volume in recent years, there was an increase in their share in the total assets of Ukrainian banks, which means a certain diversification of transac- tions with Ukrainian banks' assets.

Amosha et al. (2011) focus on the need to orient the institutional environment of our country to increase its investment attractiveness, to improve the macroeconomic investment climate, as well as on more innovation in investment projects. Blank (2001), Illyashenko (2017), Logutova (2014) and Turylo (2014) formulated approaches to system and integrated management of investment processes of enterprises under international relationships activation and their interrelation with the innovation processes effectiveness. Andrushkiv (2016) considers investment processes in the context of the sustainable development of economic systems in the conditions of European integration and raises the question of the need to form a systematic approach to the formation of such systems throughout the chain: enterprise - industry - region - state. According to Aymeric Kalife (2017), the range of issues studied outlines the specifics of investment markets in the current environment and defines the features of large transactions impact on the market stability as a whole.

The complexity of adaptation to the European society requirements is underlined by many authors. Vertakova and Plotnikov (2017), while highlighting the laws of world's sustainable development, emphasize the importance of meeting the world community requirements regarding economic, investment, environmental, social and other issues. Zatonatska (2017) analyzes the global trends of investment development, determines the importance of taking them into account while developing domestic investment policy, and suggests recommendations for their improvement.

Irtyshcheva and Sokhnych (2012) analyze innovation and investment processes from the point of 
view of adapting international experience in domestic realities and define the need to unify the approaches to managing such processes.

Baculakova and Harakalova (2017) present the results of their analysis of the current trends in the EU economy development over the past few years with benchmarks for reducing the economic processes orthodoxy in the European Union.

Krupka (2004) notes that the investment environment can be investigated both at macro and micro levels. The macroeconomic environment is shaped by variables that stimulate or restrain investment in the national economy or its individual sectors. Therefore, the microeconomic environment is represented by variables influencing the investment processes in the region. Today it can be argued that the macroeconomic investment environment in the Ukrainian economy is not at the proper level, which results in negative tendencies in investing in all sectors of the economy.

\section{METHODS}

In the course of the study, the following methods were used: system analysis and synthesis - to study the state of the domestic economy under European integration, as well as to identify reserves for the investment activity possibilities; structural and logical analysis and scientific substantiation - to construct the logic and structure of work and to form recommendations for the unification of the institutional provision of domestic enterprises' investment activities.

The purpose of the study is to give recommendations concerning the unification of institutional support for the investment environment formation in Ukraine.

\section{RESULTS}

The strategic direction of improving the economic situation in Ukraine is the European way of development. It concerns political, economic, social and all other spheres of the country's life. At the moment, the situation regarding cooperation with the European Union is characterized by significant de- velopment reserves. This thesis is supported by actual statistics. Thus, in the autumn of 2017, the Ministry of Economic Development and Trade of Ukraine released a report on the state of trade and investment cooperation between Ukraine and the European Union in January-June 2017 compared to JanuaryJune 2016. The data show an increase in volumes of foreign economic turnover with the European Union on the supply of goods and services, on the one hand, and on the other рфтв, the reduction of imports from the European Union in the total volume of imports into Ukraine in the first half of 2017.

The geographic structure of foreign trade in goods and services of Ukraine in the first half of 2017, according to the data (Trade indicators between Ukraine and the EU for the first half of 2017), accounted for $39.9 \%$ of the total foreign trade in goods and services with the EU member states (Figure 1), including: with Germany $-7.8 \%$, Poland $-5.8 \%$, Italy $-3.8 \%$, the Netherlands $-2.3 \%$, Hungary $2.3 \%$, France $-2.2 \%$, Great Britain $-2.2 \%$, and other EU countries - $14.0 \%$ of the total volume of such trade (Figure 1).

Thus, according to the Ministry of Economic Development and Trade of Ukraine, according to the first half of 2017 results, the European Union remains one of Ukraine's main trading partners: the share of trade in goods and services amounted to more than a third of the total volume of foreign trade in Ukraine during this period. In the first half of 2017, exports to the European Union increased by $22.8 \%$ or by 1737.9 million dollars and amounted to 9365.5 million dollars.

Also, in the first half of 2017, imports from the European Union increased by $21.3 \%$ or by 1858.2 million dollars in monetary terms. However, as noted, the share of imports from the European Union decreased by 2.1 points and amounted to $42.3 \%$ of the total volume of imports into Ukraine.

Estimated data on the share of export-import of goods with EU countries in the total export-import of goods of Ukraine in 2011-2016 (Table 1) indicate its constant gradual growth, which gives the right to assert on economic relations activation between Ukraine and the European Union. In the perspective of such an activation, levers of investment processes activation play an important role. 


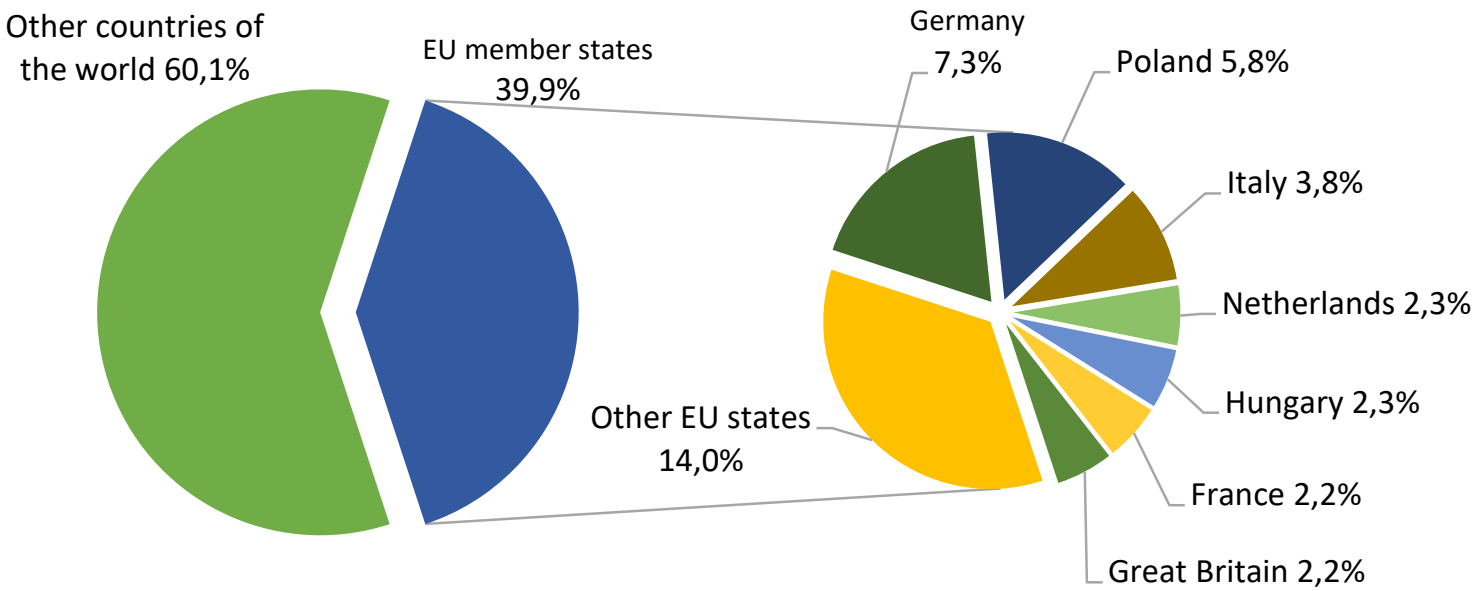

Note: Based on trade and investment cooperation data between Ukraine and the European Union (January-June 2017/January-June 2016).

Figure 1. Geographic structure of foreign trade in goods and services in Ukraine in the first half of 2017

The European Union is both a leading source and an object of direct foreign investment. Thus, according to Eurostat (Selected Principal European Economic Indicators), at the end of the third quarter of 2017, the volume of foreign direct investment, net was 1990,0 billion euros, and the volume of portfolio investment, net -2311.1 billion euros.

FDI indicators in Ukraine are incomparably lower: direct investment (share capital) from the countries of the world into the Ukrainian economy at the end of the third quarter of 2017 amounted to 39.72 billion dollars, direct investment (share capital) from Ukraine to the world economies, respectively, 6.35 billion dollars (State Statistics Service of Ukraine). The given data indicate a significant gap between the level of investment processes in the European Union and in the domestic economy and the existence of significant reserves for improving the regulation of investment activity at all its levels.

According to the European Commission (European Commission Trade Policy) data, the European Union is constantly stimulating systemic measures to intensify investment activity. So, in September 2017, the European Union proposed an improved regulatory document on promoting foreign direct investment in order to increase the economic level of its member countries. The European Union, after Lisbon Treaty went into effect, has exclusive competence regarding FDI. The European Commission

Table 1. Specific weight of export-import of goods with EU countries in total export-import of goods of Ukraine in 2011-2016

\begin{tabular}{|c|c|c|c|c|c|c|}
\hline \multirow[b]{2}{*}{ Years } & \multicolumn{3}{|c|}{ Exports } & \multicolumn{3}{|c|}{ Imports } \\
\hline & $\underset{\text { mln }}{\text { Total, USD }}$ & $\begin{array}{c}\text { To EU } \\
\text { countries, } \\
\text { USD mln }\end{array}$ & $\begin{array}{c}\text { Specific } \\
\text { weight of } \\
\text { exports to EU } \\
\text { countries in } \\
\text { total exports } \\
\text { of Ukraine, \% }\end{array}$ & $\underset{\text { mln }}{\text { Total, USD }}$ & $\begin{array}{l}\text { From EU } \\
\text { countries, } \\
\text { USD mln }\end{array}$ & $\begin{array}{l}\text { Specific weight } \\
\text { of imports from } \\
\text { EU countries in } \\
\text { total imports of } \\
\text { Ukraine, \% }\end{array}$ \\
\hline 2011 & 68394,2 & 18021,5 & 26.3 & 82608,2 & 25805,8 & 31.2 \\
\hline 2012 & 68830,4 & 17123,7 & 24.9 & 84717,6 & 26237,2 & 31.0 \\
\hline 2013 & 63320,7 & 16758,6 & 26.5 & 76986,8 & 27046,5 & 35.1 \\
\hline 2014 & 53901,7 & 17002,9 & 31.5 & 54428,7 & 21069,1 & 38.7 \\
\hline 2015 & 38127,1 & 13015,2 & 34.1 & 37516,4 & 15330,2 & 40.9 \\
\hline 2016 & 36361,7 & 13496,3 & 37.1 & 39249,8 & 17140,8 & 43.7 \\
\hline
\end{tabular}

Note: Ministry of Economic Development and Trade of Ukraine. 
Table 2. FDI of Poland

\begin{tabular}{|c|c|c|c|c|c|}
\hline \multicolumn{6}{|c|}{ Direct investment, USD bln } \\
\hline \multicolumn{3}{|c|}{ Inward direct investment from } & \multicolumn{3}{|c|}{ Outward direct investment to } \\
\hline Netherlands & 33,3 & $18 \%$ & Cyprus & 9,0 & $37 \%$ \\
\hline Germany & 29,9 & $16 \%$ & Luxembourg & 5,0 & $20 \%$ \\
\hline Luxembourg & 21,1 & $11 \%$ & Switzerland & 2,1 & $8 \%$ \\
\hline France & 20,0 & $11 \%$ & Netherlands & 1,9 & $8 \%$ \\
\hline Spain & 11,1 & $6 \%$ & Czech Republic & 0,2 & $8 \%$ \\
\hline Total received & 183,5 & $100 \%$ & Total given & 24,4 & $100 \%$ \\
\hline
\end{tabular}

Note: National Bank of Poland.

is currently working to enhance the protection of investments: it proposes to conclude a Transatlantic Partnership and Investment Agreement with the United States, strengthens the emphasis on the rights of countries to regulate investments in the interests of society, establishes more precise rules for their protection, and forms a more efficient system of state investment court for solving investment disputes (Trade Indicators of Ukraine and the EU for the first half of 2017).

As an important characteristic of the institutional environment to promote investment activity in the European Union, it is also possible to state that according to official data (Selected Principal European Economic Indicators) it is an active participant in international organizations and those where international investment rules are discussed and agreed, such as: Organization for Economic Cooperation and Development (OECD), the United Nations Conference on Trade and Development (UNCTAD), the World Trade Organization (WTO), the United Nations Commission on International Trade Law (UNCITRAL), the International Center for Settlement of Investment Disputes (ICSID), the Energy Charter, and others. According to the data of the Selected Principal European Economic Indicators within the EU, 12 member states have national mechanisms for financing investments: Austria, Denmark, Germany, Finland, France, Latvia, Lithuania, Italy, Poland, Portugal, Spain, and the United Kingdom. Mechanisms have some differences, but are fully focused on promoting investment attraction, setting qualitative and quantitative criteria for determining the quality of investments, protecting essential national security interests, and fully complying with public safety and public policy.

\subsection{Characteristics of the Polish investment environment}

Activation of investment activity and improvement of its regulation mechanisms at all levels is an important feature of Poland. At the same time, emphasis is shifted to perspective and innovative sectors and branches of its economic activity. The Polish government constantly creates effective measures at all levels to improve the country's investment climate. The Polish government focuses on the creation of appropriate infrastructure of financial support for social enterprises. Thus, it is the ES/TISE pilot program in Poland to test delivering refundable resources (loans with preferential rates) to the social economy in Poland launched. It has been established with the state-owned bank (BGK - Bank Gospodarstwa Krajowego) resources and following the guidelines established with a group of experts. The Social and Economic Investment Company TISE has been selected through BGK tender as the financial intermediary in charge of managing those resources (Lyakh, 2017).

The results of these activities are shown by the following data on foreign direct investment and portfolio investment in Poland (Tables 2 and 3), which are listed on the official website of the National Bank of Poland.

The attracted foreign direct investment in Poland's economy (USD $183.5 \mathrm{bln}$ ) is 7.5 times higher than Poland's foreign direct investment invested in economies of other countries.

The size of Poland's investment flows is significant and geographically widespread. The results of the analysis of the institutional and legislative prerequisites of high investment activity in Poland show that the investment attractiveness of the country 
Table 3. Sources of incoming portfolio investment of Poland from top five partner countries

\begin{tabular}{|c|c|c|c|c|c|c|c|c|}
\hline \multicolumn{9}{|c|}{ Portfolio investment assets, USD bln } \\
\hline \multicolumn{3}{|c|}{ Total } & \multicolumn{3}{|c|}{ Equity securities } & \multicolumn{3}{|c|}{ Total debt securities } \\
\hline All countries & 30,805 & $100 \%$ & All countries & 22,719 & $100 \%$ & All countries & 8,086 & $100 \%$ \\
\hline Luxembourg & 11,539 & $37 \%$ & Luxembourg & 0,011 & $47 \%$ & Sweden & 1,358 & $17 \%$ \\
\hline USA & 2,745 & $9 \%$ & Germany & 0,001 & $5 \%$ & France & 1,124 & $14 \%$ \\
\hline France & 1,619 & $5 \%$ & Austria & 0,711 & $3 \%$ & Luxembourg & 0,756 & $9 \%$ \\
\hline Germany & 1,520 & $5 \%$ & Great Britain & 0,599 & $3 \%$ & Hungary & 0,486 & $6 \%$ \\
\hline Sweden & 1,389 & $5 \%$ & France & 0,495 & $2 \%$ & Turkey & 0,481 & $6 \%$ \\
\hline
\end{tabular}

Note: National Bank of Poland.

provides a strategy for responsible development of the Polish government, the existence of liberal legislation, skilled, relatively inexpensive labor and proximity to major markets.

In the Strategy for Responsible Development, published on May 11, 2017, the Government of Poland has prioritized the bureaucratic processes regulation in order to facilitate business. It contributes to the economy growth in every possible way, supporting measures to increase productivity and increase foreign trade, encouraging and promoting small business development, scientific research, technological modernization and innovation. The effectiveness of the institutional support for the formation of the investment environment in Poland and the measures effectiveness are shown in Table 4.

Based on the analysis of the Polish Government's Report on the investment climate in the country in 2017 (Bureau of Economic and Business Affairs) based on the identification of its features, it is possible to systematize and characterize the measures that are used in the country to increase investment activity at the institutional level (Figure 2). At the same time, the analytical basis was the official data, published by Poland on the state, dynamics and results of the country's investment activity, the legislative and legal framework concerning the investment climate formation in Poland.
Thus, an analysis of official data on the status and institutional support for investment climate in the European Union, in the context of Poland, shows that a condition for achieving high rating indicators by these countries is the legal framework for investment promotion, which, as outlined above, includes the availability of relevant institutions, improved taxation mechanism, transparent business conditions, guarantee of monetary units' stability, etc. The emphasis is placed on the analysis of investment activity in Poland in view of a certain geographical, political, social proximity to the conditions of Ukraine.

\subsection{Characteristics of the Ukrainian investment environment}

The economy of Ukraine is in a difficult economic situation, which maintained its tendency to deteriorate in 2015 as a result of the continuing aggressive policy of the Russian Federation, the occupation of the Crimea and military operations in Eastern Ukraine. Creating favorable conditions for business climate in Ukraine remains one of the most urgent issues.

According to the State Statistics Service of Ukraine, the volume of direct investments (share capital) from the countries of the world in the economy of Ukraine as of July 1, 2017 amounted to USD 38.98 bln (Table 5).

Table 4. Indicators characterizing the effectiveness of Polish economic policy

\begin{tabular}{|c|c|c|}
\hline Indicator, year & $\begin{array}{c}\text { Unit of } \\
\text { measurement }\end{array}$ & Value \\
\hline TI Corruption Perceptions Index, CP, 2016 & Position & 29 out of 175 countries of the world \\
\hline World Bank's Doing Business Report "Ease of Doing Business", 2017 & Position & $\begin{array}{l}107 \text { out of } 190 \text { countries of the } \\
\text { world }\end{array}$ \\
\hline Global Innovation Index, 2016 & Position & 39 out of 128 countries of the world \\
\hline World Bank GNI per capita Atlas method, 2015 & USD & 13.340 \\
\hline
\end{tabular}

Note: Bureau of Economic and Business Affairs. 


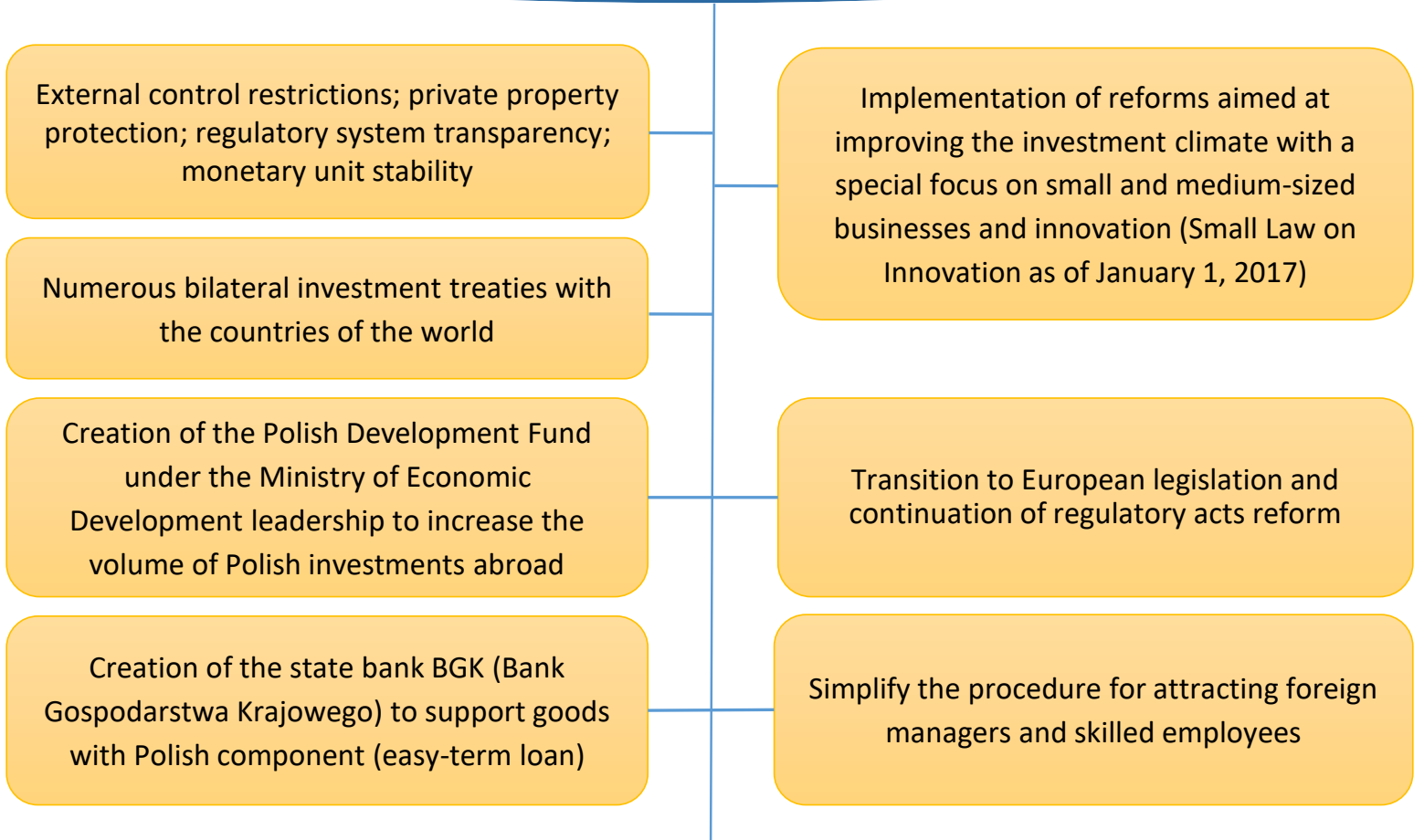

OTHER MEASURES TO IMPROVE INVESTMENT ACTIVITY

Figure 2. Measures to promote investment activity at all institutional levels (evidence from Poland)

Table 5. Direct investment (share capital) from the countries of the world to Ukraine

\begin{tabular}{l|c|c}
\hline \multirow{1}{*}{ Investor countries } & $\begin{array}{c}\text { Volume of direct } \\
\text { investment as } \\
\text { of June 1, 2017 }\end{array}$ \\
\cline { 2 - 3 } & USD bln & $\begin{array}{c}\text { As \% of the } \\
\text { total }\end{array}$ \\
\hline $\begin{array}{l}\text { Total from countries of the } \\
\text { world, including: }\end{array}$ & 38,98 & 100.0 \\
\hline Cyprus & 9,93 & 25.5 \\
\hline Netherlands & 6,33 & 16.2 \\
\hline Russian Federation & 4,44 & 11.4 \\
\hline Great Britain & 2,16 & 5.5 \\
\hline Germany & 1,74 & 4.5 \\
\hline Virgin Islands (Great Britain) & 1,68 & 4.3 \\
\hline Switzerland & 1,51 & 3.9 \\
\hline
\end{tabular}

Note: State Statistics Service of Ukraine.

As of July 1, 2017, the largest volumes of direct investment revenues were sent to institutions and organizations engaged in financial and insurance activities $-26.4 \%$, and in industrial enterprises $26.7 \%$. Consequently, the assertion about the sig- nificant reserves for the availability of investment resources in the European Union is axiomatic.

For comparative analysis with respect to the data on the represented European countries, indicators should be given characterizing the effectiveness of the Ukrainian economic policy according to the Bureau of Economic and Business Affairs (Table 6).

Compared to the respective indicators of Poland, the significance of these characteristics is critically low (see Table 6) and they indicate significant problems with the formation of a favorable investment environment. It should be noted that only The Global Innovation Index 56 out of the 128 countries is relatively positive for Ukraine. The high significance of this index was achieved due to the high level of innovative activities in Ukraine.

Corruption perceptions and the Index of Ease of Doing Business for Ukraine are critically negative. 
Table 6. Indicators characterizing the effectiveness of Ukraine's economic policy (compared to the relevant indicators of Poland)

\begin{tabular}{|c|c|c|c|}
\hline \multirow{2}{*}{ Indicator, year } & \multirow{2}{*}{ Unit of measurement } & \multicolumn{2}{|c|}{ Value for a country } \\
\hline & & Poland & Ukraine \\
\hline TI Corruption Perceptions Index, CP, 2016 & $\begin{array}{l}\text { Position out of } 175 \\
\text { countries of the world }\end{array}$ & 29 & 131 \\
\hline $\begin{array}{l}\text { World Bank's Doing Business Report "Ease of } \\
\text { Doing Business", } 2017\end{array}$ & $\begin{array}{l}\text { Position out of } 190 \\
\text { countries of the world }\end{array}$ & 107 & 80 \\
\hline Global Innovation Index, 2016 & $\begin{array}{l}\text { Position out of } 128 \\
\text { countries of the world }\end{array}$ & 39 & 56 \\
\hline World Bank GNI per capita Atlas method, 2015 & USD & 13340 & 712 \\
\hline
\end{tabular}

Note: Compiled based on Bureau of Economic and Business Affairs data.

Comparing them with the values of such indices for Poland (Table 6) allows us to confidently state that the most important directions in ensuring the formation of a favorable investment environment for Ukraine is the adoption of urgent measures to overcome corruption and simplify business.

At the moment, the following aspects of investment activity are also problematic for Ukraine:

- the need to optimize the financial leverage of investment activity regulation at the macro level;

- the need to create an appropriate institutional environment adapted to the requirements of the effective functioning of the mechanism for investing in the domestic enterprises development;

- intensifying cooperation between state institutions and direct subjects of investment and innovation activity in view of their adaptation to the requirements of European economic policy;

- the need to improve the technical issues of the mechanism of attraction, allocation of investments and control over their target direction.

As part of economic and administrative reforms, institutional and infrastructural changes in the field of investment policy regulation take place, as it is at this level that the fundamentals of financing the activities of domestic enterprises during the period of European integration are formed.

In order to facilitate the processes of attracting financial resources to the Ukrainian economy, in- cluding in innovative projects, the Government of the country, in accordance with the Order of the Ministry of Economic Development of Ukraine No. 723 dated May 18, 2017, created an investment attraction department, which has the functions of developing proposals concerning the support for the formation and implementation of state investment policy in the field of public-private partnership and in the sphere of the functioning of industrial parks, ensuring the implementation of state policy in the field of innovation activity as an integral part of investment activity, implementation of international measures for the formation of a positive investment image, promotion of foreign investors in Ukraine.

Creation of the investment attraction department is the most important event at the macro level, since the concentrating enforcement procedures of the Ukrainian government on the intensification of investment processes (including the attraction of foreign investments) in one institution is a factor that will accelerate the speed of such measures implementation, as well as increase their quality and performance. It is also important to note that in addition to the above functions, this department should also prepare and consider proposals for the creation and functioning of special (free) economic zones, priority development territories, free customs zones of industrial grade, clusters, technological and scientific parks, other tools and mechanisms for promoting investment, innovation and research activities.

Such structural shifts are positive, effective and oriented to European standards, since in such conditions virtually all progressive spheres and forms of investments attraction (including innovations) will have a single body of government, 
regulation, research and coordination. Based on the principles of complementarity and synergy, these developments will lead to the optimal effect through systematic, permanent and effective implementation of the measures being developed by the abovementioned department. Such measures should be based on the principles of interaction between business and government, public-private partnership, regulated by the Law of Ukraine "On Public-Private Partnership" No. 2404-VI as of July 01, 2010.

According to information released by the Ministry of Economic Development and Trade of Ukraine on January 1, 2017 on the results of the public-private partnership implementation, based on publicprivate partnership, 186 projects were analyzed. It should be noted that for Ukraine, the urgency and importance of implementing measures in these areas are obvious, as they accompany investments in innovation in segments such as waste recycling, improving the environmental situation, production of energy from alternative sources, transport infrastructure improvement, etc., and boost the well-being of Ukraine's population.

Thus, subject to the development of appropriate tools and the creation by the state of legislative, financial, organizational conditions for the effective support for effective safeguards and economic security of enterprises that are participants in such projects, it is possible to predict a significant increase in the implementation of such projects, as their riskiness will decrease. In our opinion, the most important thing in these projects is that they are implemented in problematic activity areas, thereby increasing the domestic products competitiveness. According to the synergy effect, such enterprises, acting as reference in their areas, will, in turn, form a certain institutional and infrastructure network, based on which innovation-investment activity of other enterprises (both in the form of clusters and other forms) will be activated.

We believe that intensifying cooperation between the investment attraction department and the OECD (State of investment activity in Ukraine) is the government's topical macroeconomic measure to intensify the policy of European integration aimed at attracting additional investments into the domestic enterprises development. An important strategic event in terms of such a policy is that the Government of Ukraine has signed an Agreement with the OECD on accession to the Declaration on International Investments and Multinational Enterprises. In addition, the following practical tools were developed to put the Agreement in place: relevant recommendations and procedural decisions of the Council of the OECD, an overview of the Ukrainian investment policy. In our opinion, Ukraine's accession to the Declaration on International Investments and Multinational Companies was an important step towards intensification of European integration (Order of the Cabinet of Ministers of Ukraine as of August 18, 2017, No. 567-p "On Submission for Ratification by the Verkhovna Rada of Ukraine (in terms of exchange of letters) between the Government of Ukraine and the Organization for Economic Cooperation and Development concerning joining the Declaration on International Investments and Multinational Enterprises, the relevant Recommendations and Procedural Decisions of the Councils and the Organization for Economic Cooperation and Development").

Institutional changes to improve the mechanism for attracting investments should be based on the development and implementation of a system of interconnected and complementary measures aimed at increasing the domestic economy investment attractiveness.

Figure 3 shows the systematization of directions for improving the mechanism of investment and innovation activity in Ukraine, which is being implemented by the Ministry of Economic Development and Trade of Ukraine (State of investment activity in Ukraine). The institutional levers are shown to be most effective and relevant for this stage of the country's economic development.

We believe that positive thing in the European integration of Ukraine is that, in order to intensify investment activity, promote stable economic development and protect investors' rights, the Government of the country is constantly implementing new solutions, such as amending the Budget Code of Ukraine regarding state investment projects, developing new project selection procedures, updating and simplifying the list of requirements for state investment projects, imple- 


\section{MAIN DIRECTIONS TO IMPROVE INSTITUTIONAL SUPPORT FOR INVESTMENT ACTIVITY IN UKRAINE}

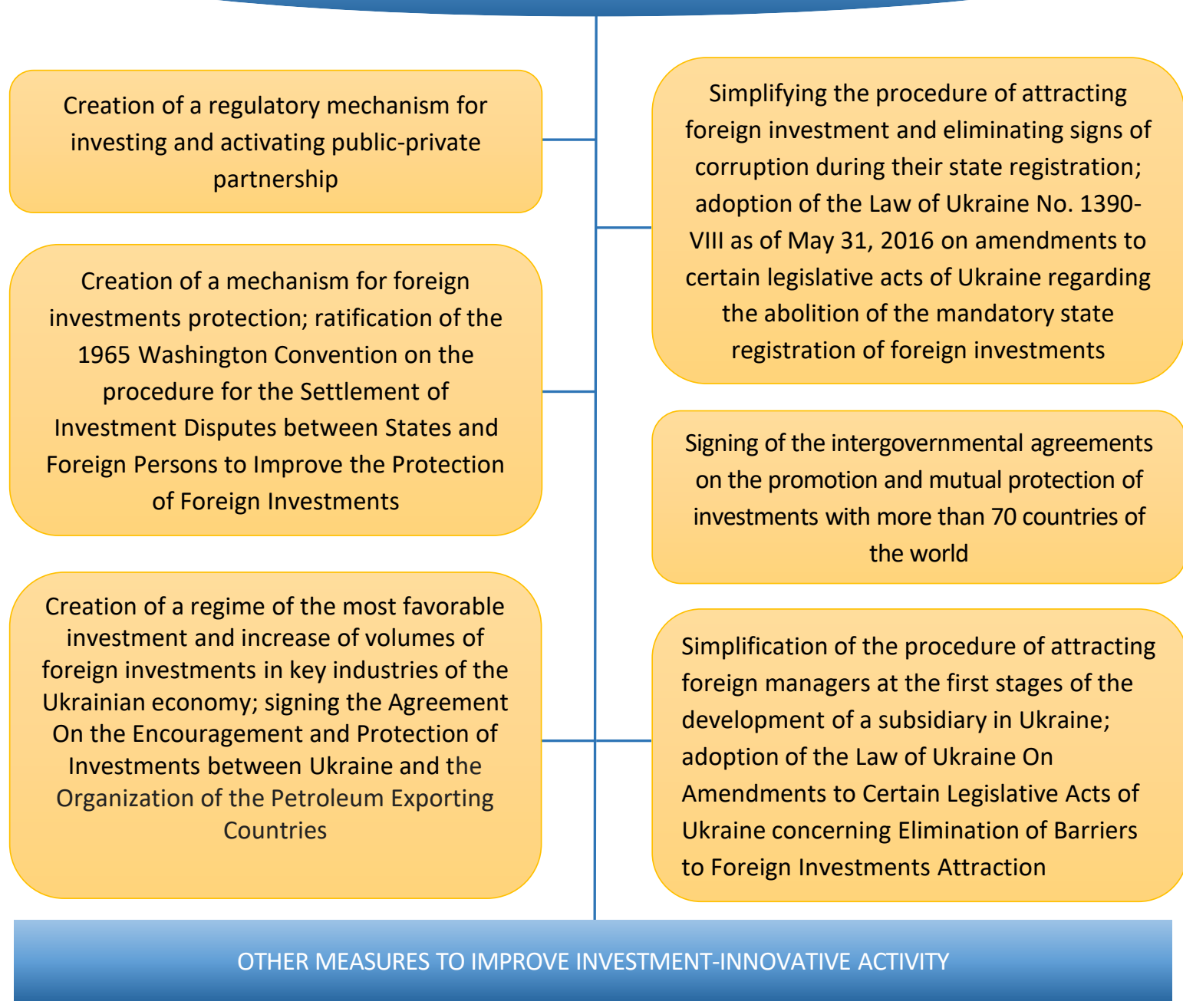

Figure 3. Directions to improve institutional support for investment activity in Ukraine

mentation of measures for state support for the industrial parks construction, exemption from import duties of goods imported by foreign investors for a period of not less than three years for the purpose of investing on the basis of registered contracts or as a contribution of a foreign investor to the statutory capital of an enterprise with foreign investments, etc.

Concerning the intensification of investment processes in Ukraine and the compatibility of legislative and institutional support of investment activity with Western standards at the enterprise level, as the basic structural unit of the country's economic system, the following should be noted. Obviously, after entering Ukraine into the European economic space, only competitive products and services have prospects to remain in the market of goods and services. Therefore, during the period of European integration in order to increase compliance with the European standards and to intensify the formation of an investment environment, in addition to measures aimed at increasing the efficiency and competitiveness of investment activity at the micro level, the following steps can also be suggested:

1) the shift of emphasis from long-term investments to the short-term ones, since in today's turbulence conditions of the domestic economy, the reduction of the payback period of investments is an important factor in their attraction; 
2) unification of regulatory and formal requirements for the investment projects execution taking international standards into account;

3) focusing on promising areas and branches of management while developing investment projects: introduction of energy saving technologies; waste treatment, water and natural air purification; construction and maintenance of highways, roads and railways; recreation, culture, sports, etc. in order to simplify the rationale for the conclusion of contracts within the framework of public-private partnership;

4) taking into account, in the conditions of economic instability, the prospects for the beginning of the economic recovery period and the state of potential investment;

5) using the advantages of small and mediumsized businesses, namely, greater adaptability, maneuverability, the possibility of reducing the payback period of investments and activating their innovation and investment activity (both with the attraction of direct and indirect investment);

6) the development by the enterprise management of special measures to attract both domestic and international investments on the terms of foreign economic contracts;

7) increasing the accuracy of the planned calculations for the investment projects evaluation by using, during such calculations, the methodology of the National Bank of Ukraine in terms of calculating the cumulative adequacy ratio of discounted cash flows for a loan for the investment project implementation, etc.

The results of the present research are intended to facilitate the investment mechanism improvement, including innovation activity, at all levels of management during the period of Ukraine's integration into a single European space.

\section{CONCLUSION}

The development of Ukraine during its integration into the European Economic Area is inextricably linked with the formation of a favorable investment climate in the country. The analysis of the indicators characterizing the investment environment of Ukraine in comparison with the relevant indicators of Poland showed that the most important for our country are problems such as significant level of corruption and the complexity of doing business. The situation is also complicated by the imperfect system of institutional support for the investment processes regulation in Ukraine. The measures proposed in the work based on the systematization of directions of the investment activity improvement are intended to promote the attractiveness of the domestic investment environment.

\section{REFERENCES}

1. Amosha, O. I. et al. (2011). Структурні реформи економіки: світовий досвід, інститути, стратегії для України [Strukturni reformy ekonomiky: svitovyi dosvid, instytuty, stratehii dlia Ukrainy] (pp. 118-122). Ternopil: Ekonomichna Dumka.

2. Andrushkiv, B. M., Melnyk, L. M., \& Pohaidak, O. B. (2016). Інноваційні засоби формування концепції оцінювання сталого розвитку у системі: підприємство - галузь - регіон - держава (Євроінтеграційні аспекти) [Innovatsiini zasoby formuvannia kontseptsii otsiniuvannia staloho rozvytku u systemi: pidpryiemstvo - haluz - rehion - derzhava] (Yevrointehratsiini aspekty). Ukrainskyi zhurnal prykladnoi ekonomiky, 1(2), 6-17.

3. Ashauer, D. (1989). Productive Investment and Productivity in the Group of Seven. Economic Perspectives, 13, 17-25.

4. Association Agreement between the European Union and its Member States, of the one part, and Ukraine, of the other part. EUR-
Lex Access to European Union law. Retrieved from http://eur-lex. europa.eu/legal-content/EN/ALL /?uri=CELEX:22014A0529(01)

5. Awolusi, O. D., \& Adeyeye, O. P. (2016). Impact of foreign direct investment on economic growth in Africa. Problems and Perspectives in Management, 14(2-2). http:// dx.doi.org/10.21511/ppm.14(22). 2016.04

6. Aymeric Kalife (2017). Managing investment and liquidity risks for derivatives within a market impact perspective. Insurance 
Markets and Companies, 8(1), 59-73. http://dx.doi.org/110.21511/ ins.08(1).2017.06

7. Baculakova, K., \& Harakalova, L. (2017). Creative industries in the EU: factors influencing employment. Economic AnnalsXXI, 164(3-4), 40-44.

8. Blank, I. A. (2001).

Инвестиционный менеджмент: учебный курс [Investitsionnyy menedzhment: uchebnyy kurs] (448 p.). Kiev: Elga, Nika-tsentr.

9. Bureau of Economic and Business Affairs. Poland. 2017 Investment Climate Statements. Retrieved from https://www.state.gov/e/eb/rls/ othr/ics/2017/eur/269940.htm

10. Business and Investment Development Agency. Investment Climate. Retrieved from http:// www.businessinfo.cz/en/articles/ text-investment-climate-8261.html

11. European Comission. Trade Policy. Accessing markets. Investment. Retrieved from http://ec.europa. eu/trade/policy/accessing-markets/ investment

12. Illyashenko, S. M., Bozhkova, V. V., \& Derykolenko, O. M. (2017) Approaches to Industrial Project Assessment and Selection in the Ukraine Based on "Risk Benefit". In A. Jabłoński, Sustainability and Scalability of Business: Theory and Practice (pp. 247-266). New York: Nova Science Publishers, Inc.

13. Investment Climate Statements 2017 - Department of State. Bureau of economic and business affairs. Retrieved from https://www. state.gov/e/eb/rls/othr/ics/2017/ eur/269896.htm

14. Irtyshcheva, I. O., \& Sokhnych А. Үa. (2012). Інноваційний розвиток сільських територій: адаптація міжнародного досвіду в національних реаліях [Inпоvatsiinyi rozvytok silskykh terytorii: adaptatsiia mizhnarodnoho dosvidu $v$ natsionalnykh realiiakh] (176 p.). Mykolaiv: Ilion.

15. Krupka, I. M. (2004). Формування макроекономічного інвестиційного середовища в Україні [formuvannia makroekonomichnoho seredovyshcha $\mathrm{v}$ Ukraini]. Finansy Ukrainy, 4, 87-97.
16. Law of Ukraine on State-Private Partnership (2010). No. 40, Ar. 524. Kyiv, July 1, 2010, No. 2404VI. Retrieved from http://zakon3 rada.gov.ua/laws/show/2404-17

17. Logutova, T. G., Kapranova, L. G., \& Kapranov, M. A. (2014). Investment climate in cases of force majeure. Visnyk Pryazovskoho derzhavnoho Tekhnichnoho Universytetu, Zb. nauk. prats 28 , 259-266. Mariupol: PDTU.

18. Lyakh, O. (2017). Institutional aspects of the social enterprises' sector development (case for Poland and Ukraine). Geopolitics Under Globalization, 1(1), 17-29. https:// doi.org/10.25161/gg.1(1).2017.03

19. Major, K., \& Sziagyi, K. (2009). Government investment in a small open economy. Acta Oeconomica, 59(2), 119-145.

20. Ministry of Economic Development and Trade of Ukraine (2017). Довідка щодо результатів здійснення державноприватного партнерства за 2016 рік. Загальний огляд [Dovidka shchodo rezultativ zdiisnennia derzhavno-pryvatnoho partnerstva za 2016 rik. Zahalnyi ohliad]. Retrieved from http://www.me.gov.ua/ Documents/Detail?lang=ukUA\&id=ed00a2ba-480a-497984eb-d610a0827a8c\&title=Zagaln iiOgliad

21. Ministry of Economic Development and Trade of Ukraine (2017). Показники торгівлі України з ЄС за I півріччя 2017 року [Pokaznyky torhivli Ukrainy z EU za I pivrichchia 2017 poku]. Retrieved from http://www.me.gov. ua/Documents/Detail?lang=ukUA\&id=295d6f93-bc8a-4e2f-a145a4a32770e05a\&title=PokaznikiTorgivliUkrainiZsZaIPivrichchia2017-Roku

22. Ministry of Economic Development and Trade of Ukraine (2017). Положення про Департамент залучення інвестицій [Polozhennia pro Departament zaluchennia investytsii]. Retrieved from http:// www.me.gov.ua/Documents/ List?lang=uk-UA\&id=bc94e3dec9a7-4b43-bb0e-bcb515ee6a0c\& tag $=$ SpivrobitnitstvoZOrganizats
iiuEkonomichnogoSpivrobitnits tvaTaRozvitku

23. Ministry of Economic Development and Trade of Ukraine (2017). Торговельне та інвестиційне співробітництво між Україною та Європейським Союзом (січень-червень 2017 р./ січеньчервень 2016 р.). Загальний огляд. [Torhovelne ta investytsiine spivroditnytstvo mizh Ukrainoiu ta Yevropeiskym Soiuzom (sichencherven 2017/ sichen-cherven 2016). Zahalnyi ohliad]. Retrieved from http://www.me.gov.ua/ Documents/Detail?lang=ukUA\&id=295d6f93-bc8a-4e2f-a145a4a32770e05a\&title $=$ PokaznikiTorgivliUkrainiZsZaIPivrichchia2017-Roku

24. Ministry of Economic Development and Trade of Ukraine. Інвестиційна діяльність в Україні. Інвестиційний клімат в Україні у 2017 році. Звіт [Investytsiina diialnist v Ukraini. Investytsiinyy klimat $\mathrm{v}$ Ukraini u 2017 potsi. Zvit]. Retrieved from http://www.me.gov.ua/Documents $/$ Download?id $=406 \mathrm{e} 7 \mathrm{~b} 4 \mathrm{c}-$ b2a1-40ec-811e-30464ad564e3

25. Ministry of Economic Development and Trade of Ukraine. Стан інвестиційної діяльності в Україні. Департамент залучення інвестицій [Stan investytsiinoi diialnosti v Ukraini. Departament saluchennia investytsii]. Retrieved from http://www.me.gov.ua/Documents/List?lang=uk-UA\&ta

26. National Bank of Poland (2017). Retrieved from http://www.nbp.pl/

27. Poland launches "Strategy for responsible development". Retrieved from http://nowyjorkonz.msz. gov.pl/en/news/poland_launches_strategy_for_responsible_ development_?channel $=$ www

28. Selected Principal European Economic Indicators. European Commission. Eurostat. Euroindicators/PEEIs. Retrieved from http://ec.europa.eu/eurostat/web/ euro-indicators/peeis

29. State Statistics Service of Ukraine (2018). Офіційні статистичні дані про іноземні інвестиції України. Прямі інвестиції (акціонерний 
капітал) з країн світу в економіці України [Ofitsiini statystychni dani pro inozemni investytsii Ukrainy. Priami investytsii (aktsionernyi capital) z krain svitu v ekonomitsi Ukrainy]. Retrieved from http://www. ukrstat.gov.ua/

30. Tkachuk, I. (2017). Asset operations of Ukrainian banks on the current stage of banking system development. Banks and Bank Systems, 12(1-1), 119-127. http:// dx.doi.org/10.21511/bbs.12(11).2017.04

31. Turylo, A. M., Zinchenko, O. A., \& Turylo, A. A. (2014). Суспільний інноваційний розвиток і теоретико-методологічні підходи до визначення науково-практичної категорії “економічний менеджмент підприємства" [Suspilnyi in- novatsiinyi rozvytok i teoretykometodolohichni pidkhody do vyznachennia naukovo-praktychnoi katehorii "ekonomichnui menedzhment pidpryiemstva"]. Aktualni Problemy Ekonomiky, 9(15), 60-64.

32. Verkhovna Rada of Ukraine Розпорядження Кабінету Міністрів України від 18 серпня 2017 p. № 567-p “Про подання на ратифікацію Верховною Радою України Угоди (у формі обміну листами) між Урядом України та Організацією економічного співробітництва та розвитку щодо приєднання до Декларації про міжнародні інвестиції і багатонаціональні підприємства, відповідних Рекомендацій та процедурних Рішень Ради Організації економічного співробітництва та розвитку" [Rozporiadzhennia Kabinetu Min- istriv Ukrainy vid 18 serpnia 2017 r. No. 567-p "Pro na ratyfikatsiiu Verkhovnoiu Radoiu Ukrainy (u formi obminu lystamy) mizh uriadom Ukrainy ta OECD shchodo pryiednannia do Deklaratsii pro mizhnarodni investytsii i bahatonatsionalni pidpryiemstva, vidpovidnykh Rekomendatsii ta protsedurnykh rishen Rady Orhanizatsii ekonomichnoho spivrobitnytstva ta rozvytku"]. Retrieved from http:// zakon3.rada.gov.ua/laws/show

33. Vertakova, Yu., \& Plotnikov, V. (2017). Problems of sustainable development worldwide and public policies for green economy. Economic Annals-XXI, 166(7-8), 4-10.

34. Zatonatska, T. (2016). Global trends in state investment policy and practice of their implementation in Ukraine. Economic AnnalsXXI, 156(1-2), 26-30. 